\title{
0 Sexto Sentido e a sexta-feira 13: narrativas da Igreja Universal em um programa televisivo da Rede Record em Portugal
}

\section{Marco Túlio Sousa ${ }^{1}$ Donizete Rodrigues ${ }^{2}$}

Recibido: 2014-10-31

Enviado a pares: 2014-11-06
Aprobado por pares: 2014-12-04

Aceptado: 2015-01-14

DOI: 10.5294/pacla.2015.18.2.10

Para citar este artículo / To reference this article / Para citar este artigo

Sousa, M.T., Rodrigues, D. Junio de 2015. 0 Sexto Sentido e a sexta-feira 13: narrativas da Igreja Universal em um programa televisivo da Rede Record em Portugal. Palabra Clave 18(2), 563-587. DOI: 10.5294/pacla.2015.18.2.10

\section{Resumo}

Este trabalho tem como objetivo contribuir para um melhor entendimento sobre a participação da Igreja Universal do Reino de Deus (IURD) na mídia em Portugal e como essa denominação brasileira se relaciona com a sociedade portuguesa e com as suas especificidades religiosas. Para a análise foram selecionadas cinco edições do Sixth Sense (programa de tevê da IURD em Portugal), em que há referências à sexta-feira 13, data cheia de misticismo no catolicismo popular. Com base na teoria narrativa de Paul Ricoeur, foi realizada uma análise de conteúdo dos programas, na qual se descortinou a cosmologia dessa igreja neopentecostal: um "mundo" onde forças antagônicas, que representam o Bem e o Mal, lutam entre si para dominar/

1 Professor do curso de Comunicação Social da Faculdade Pitágoras de Divinópolis, Brasil. Mestre em Comunicação Social pela Universidade Federal de Minas Gerais, Brasil. marcotuliosousa@hotmail.com

2 Professor do Departamento de Sociologia da Universidade da Beira Interior, Portugal. Doutor em Antropologia social pela Universidade de Coimbra. Associado em Antropologia, com Agregação em Sociologia.

donizetti.rodrigues@gmail.com 
salvar as pessoas; a magia e as religiões espiritualistas são os agentes dominadores malignos, enquanto a IURD é o agente do bem, da salvação.

\section{Palavras-chave}

Igreja Universal do Reino de Deus, Portugal, mídia, teoria narrativa, religiosidade (Fonte: Tesauro da Unesco).

\section{El sexto sentido y el viernes 13: narrativas de La Iglesia Universal en un programa televisivo de la Rede Record en Portugal}

\section{Resumen}

Este trabajo tiene como fin aportar a un mejor entendimiento acerca de la participación de la Iglesia Universal del Reino de Dios (IURD) en los medios en Portugal y cómo esa denominación brasileña se relaciona con la sociedad portuguesa y con sus especificidades religiosas. Para el análisis se seleccionaron cinco ediciones del Sexto Sentido (programa de televisión de la IURD en Portugal), en que hay referencias al viernes 13, fecha llena de misticismo en el catolicismo popular. Con base en la teoría narrativa de Paul Ricoeur, se realizó un análisis de contenido de los programas, en la que se descortinó la cosmología de esa iglesia neopentecostal: un "mundo" donde fuerzas antagónicas, que representan el Bien y el Mal, luchan entre sí para dominar/salvar las personas; la magia y las religiones espiritualistas son los agentes dominadores malignos, mientras que la IURD es el agente del bien, de la salvación.

\section{Palabras clave}

Iglesia Universal del Reino de Dios, Portugal, medios de comunicación, teoría narrativa, religiosidad (Fuente: Tesauro de la Unesco). 


\section{The Sixth Sense and Friday the 13th: Narratives from the Universal Church in a Television Program Rede Record in Portugal}

\section{Abstract}

This study aims to contribute to a better understanding of the participation of the Universal Church of the Kingdom of God (UCKG) in the media in Portugal and how this Brazilian denomination is related to Portuguese society and religious specificities. For the analysis, five editions of Sixth Sense (TV UCKG in Portugal) were selected, in which there are references to Friday the 13th, a date full of mysticism in popular Catholicism. Based on the narrative theory of Paul Ricoeur, a content analysis of the programs in which it uncovered the cosmology of the Neo-Pentecostal church: a "world" where opposing forces, representing good and evil, fighting between yes to master / save people; magic and spiritualist religions are evil ruler agents, while the UCKG is the agent of good, salvation.

\section{Keywords}

Universal Church of the Kingdom of God, Portugal, media, narrative theory, religiosity (Source: Unesco Thesaurus). 


\section{Introdução}

A história da Igreja Universal do Reino de Deus (IURD) está intimamente ligada à mídia. Onde se instala, a IURD procura também ocupar espaços nos diferentes meios de comunicação, o que dá, assim, visibilidade às suas práticas e amplia as formas de contato com a população. Esta é uma característica que marca o seu percurso desde os seus primórdios, no fim da década de 1970, quando Edir Macedo possuía um programa de 15 minutos na rádio Metropolitana do Rio de Janeiro, que sucedia ao de uma mãe de santo. Rivalizando com o programa anterior, ele propunha que as soluções espirituais ofertadas pela sua igreja eram mais eficientes (Mafra, 2001, p.39).

O relato demonstra a importância de se refletir sobre as relações da IURD com a mídia, a fim de melhor compreender sua inserção e o papel da igreja em diferentes contextos e grupos sociais. Partindo dessa premissa, propomos analisar o programa Sexto Sentido, de propriedade da IURD-Portugal, em algumas edições de julho de 2012. Focaremos nos quadros sobre a sexta-feira 13, procurando entender de que modo essa igreja lida com as referências de um universo social e religioso distinto do de sua origem. Como base teórica, iremos nos apoiar em Paul Ricoeur (2010a, 2010b) e nas discussões sobre narrativa televisiva de autores do campo das ciências da comunicação. Antes, porém, faz-se necessário recuperar o histórico da IURD em Portugal.

\section{Neopentecostalismo e a Igreja Universal do Reino de Deus}

É pertinente relembrar a classificação proposta por Ari Oro (2007) que define a IURD a partir de três características fundamentais: "igreja religiofágica”; "igreja macumbeira” e "igreja da exacerbação".

A primeira expressão dá conta do modo como a IURD constrói o seu repertório simbólico operando uma "fagocitose religiosa", ou seja, incorporando crenças e ritualidades de outras igrejas e práticas religiosas, mesmo as consideradas adversárias, nomeadamente a Igreja Católica, a Umbanda, o Candomblé e o Kardecismo. Um bom exemplo consiste na crença de 
que a sexta-feira 13 é um dia amaldiçoado, referência que a IURD busca no catolicismo popular. Como "igreja macumbeira" enfatiza a apropriação de rituais e elementos simbólicos da Umbanda e do Candomblé: roupas brancas, galhos de arruda e de termos como "trabalho", "despacho", "amarrar” etc. Já "igreja da exacerbação” consiste em se ampliar elementos que vêm de uma herança recebida: presença forte na política, preferência por espaços grandes (cinemas, teatros) e suntuosos, localizados em pontos estratégicos e de fácil acesso por transporte público. O melhor exemplo é o Templo de Salomão, inaugurado em julho de 2014, em São Paulo, com espaço para 10 mil pessoas sentadas. A “igreja da exacerbação" também diz respeito ao alto investimento na mídia. A IURD conta hoje com o jornal impresso Folha Universal (tiragem semanal de 1,5 milhão de exemplares), o portal Universal.org (http:/ /www.universal.org), a Line Records, maior gravadora gospel do Brasil, e 71 emissoras de rádio (Modesto, 2012).

No campo televisivo, a IURD é detentora de 23 emissoras, dentre elas o seu maior empreendimento midiático, a TV Record, adquirida em 1989. A seguir a ainda dominante Rede Globo de Televisão, a Record disputa com o SBT (Sistema Brasileiro de Televisão) o segundo lugar em audiência no Brasil. A emissora conta com ampla abrangência em território brasileiro e tem canais na Europa, África, Ásia, Oceania e nos Estados Unidos. Além de telejornais, filmes, novelas, programas de variedade, dentre outros, a presença da Record nesses locais também faz chegar programas do tipo do Sexto Sentido, em Portugal.

Desde quando se instalou em Portugal, em dezembro de 1989, a IURD procurou adquirir espaços na mídia local; em 1992, já contava com programas em rádios do Porto (Placard) e de Lisboa (Miramar e Audissintra), o que levou, em pouco tempo, a um forte processo de expansão (Ruuth \& Rodrigues, 1999).

Nesse país, a IURD enfrentou forte resistência. O episódio mais marcante e polêmico ocorreu em 1995, com a tentativa de compra do Coliseu do Porto, espaço de grande importância cultural. Após protestos de grupos de artistas e pessoas públicas e das críticas da mídia, a negociação foi 
cancelada. A IURD enfrentou tais dificuldades com a estratégia de vitimização e com um discurso já utilizado no Brasil: as adversidades serviriam de estímulo ao trabalho de evangelização e crescimento da igreja, pois “a oposição é um desafio que inevitavelmente encontram os representantes de Deus [...] e persistir e seguir em frente torna-se a prova do mérito do crente" (Swatowiski, 2010, p. 175).

Outra maneira de superar essa crise midiática foi a reconfiguração da estratégia de implantação no país. A liderança passou a ter mais cuidado com as críticas à Igreja Católica, principalmente nos veículos de comunicação de propriedade da IURD. Outro ponto importante a se destacar consiste no fato de que, a partir de 2003, os templos passaram a se chamar “Centros de Ajuda Espiritual”. De acordo com Swatowiski (2010),

\begin{abstract}
a mudança para "Centro de Ajuda Espiritual" sugere uma tentativa de dissociar a imagem da denominação à pretensão de ser uma igreja e aponta para um local de prestação de serviços espirituais. Aqui, é interessante lembrar a ponte que se cria com os grupos chamados new age, onde [sic] a palavra "espiritualidade" é utilizada em contraposição à religião enquanto instituição que propõem a adesão doutrinária. 0 novo nome do espaço de culto da IURD também se aproxima do contexto new age na medida em que sugere uma imbricação entre terapêutica e "espiritualidade" (pp. 181-182, grifos nossos).
\end{abstract}

Outro ponto importante a salientar é o seu caráter sincrético e adaptativo; nos países em que procura fixar, a IURD tenta incorporar elementos e simbolismos da cultura local. Embora os rituais e a demonização de outras religiões permaneçam, a sua relação com outras práticas e instituições religiosas são diferenciadas. Tais aspectos são de fundamental importância para entendermos o modo pelo qual o Sexto Sentido narra a sexta-feira 13. Porém, antes de passarmos à análise, apresentaremos alguns tópicos da teoria narrativa de Paul Ricoeur que orienta o nosso olhar sobre o objeto etnográfico em questão.

\title{
Paul Ricoeur e a tríplice mimesis
}

Na vasta produção intelectual do filósofo Paul Ricoeur (1913-2005), a preocupação com a linguagem e suas formas de expressão é uma constante. No 
tocante à narrativa, encontra-se a obra Tempo e Narrativa, em que ele analisa as narrativas historiográficas e ficcionais. Essa obra é uma importante referência para o nosso trabalho, uma vez que a partir das ideias de Ricoeur objetivamos refletir sobre como as narrativas iurdianas no Sexto Sentido nos informam das relações que a IURD estabelece com a sociedade portuguesa.

Segundo Paul Ricoeur (2010a), a narrativa articula caracteres temporais que nos informam sobre a experiência do ser no mundo e no tempo. Tempo este que não é o tempo cronológico, passível de ser medido, mas aquele que cada um vivencia em suas experiências particulares e que "passa" de modo diferente para cada um. Apoiando-se em Santo Agostinho, Ricoeur discute as aporias do tempo e não encontra uma solução para elas. No entanto, encontra um caminho possível para entender nossa experiência do tempo — as narrativas funcionariam como uma mediação para a nossa experiência temporal-.

Nas narrativas podemos observar diferentes recursos e modos de contar que expressam durações de tempos vividos. A alma se estende e se distende, o que configura no narrar um modo particular de experimentar o tempo. Nesse ponto, Ricoeur vai a Aristóteles para discutir as propriedades das narrativas. Na Poética, Aristóteles chega a dois conceitos fundamentais: mimesis e mythos.

A mimesis corresponde a uma cópia criativa da realidade pela qual a ação é representada. As narrativas não são descrições que nos dizem de um estado fixo das coisas. Pelo contrário, compõem-se de deslocamentos, rupturas, movimentos de sujeitos inscritos em uma história organizada, passível de ser entendida. Ricoeur formula a noção de "tríplice mimese", que deixa mais evidente o caráter dinâmico da narrativa.

A Mimese I diz respeito a um mundo pré-configurado a que o sujeito tem acesso a partir da sua experiência no mundo da ação efetiva; abrange dimensões estruturais, simbólicas e temporais. A dimensão estrutural refere-se às formas narrativas de uma sociedade, às regras já estabilizadas e que informam os recursos narrativos mais adequados para cada situação. 
A simbólica congrega valores morais e éticos, os mitos fundantes de uma cultura. A terceira corresponde aos caracteres temporais que imprimimos às narrativas que possibilitam situar acontecimentos em uma ordem temporal, seja cronológica ou psicológica.

A Mimese II consiste no "tecer a intriga" e tem papel de mediação entre o mundo que precede a narrativa e aquele que se cria quando ela é colocada em circulação. Abre-se o reino do "como se", ou seja, de um mundo configurado narrativamente que se alicerça em uma compreensão do existente e ao mesmo tempo (re-)cria e lhe atribui novos sentidos.

A Mimese III corresponde à leitura, quando o "mundo do texto" e o "mundo do leitor" se encontram e transformam tanto o texto quanto o leitor por meio da interpretação. Há sempre desvio e permanência, bem como reafirmações e tensões nesse encontro de mundos.

Tais tensões ficam ainda mais claras se formos ao conceito de mythos, que significa "pôr em intriga". Ao tecer a narrativa, os sujeitos amarram fragmentos como eventos, sujeitos, intenções, objetivos, meios, fins em um todo passível de ser entendido. Trata-se de um processo de "concordância-discordante”. Segundo Ricoeur (2010a, p. 77), "a arte de compor [poiesis] consiste em fazer parecer concordante essa discordância: 'um por causa do outro' prevalece então sobre o 'um depois do outro'. É na vida que o discordante acaba com a concordância, não na arte trágica”. Na tessitura da intriga a conexão lógica entre os "discordantes" sobrepõe-se a um simples encadeamento cronológico de fatos.

$\mathrm{Na}$ análise tais tensões emergem na configuração das narrativas e também no mundo social que descobrimos pela operação de leitura que nós, enquanto sujeitos que as analisam, procuramos entrever. Assim, ao olhar para as narrativas do Sexto Sentido nosso cuidado volta-se para as tensões que elas dão a ver, o que dizem da sociedade portuguesa e da forma como a IURD se inscreve nessa realidade. Da mesma forma, não podemos perder de vista a inserção daqueles que narram e como o fazem. Passemos à análise. 


\title{
0 Sexto Sentido ${ }^{3}$
}

O Sexto Sentido foi criado no primeiro semestre de $2010^{4}$ e veiculado pela TV Record Europa por quase três anos, de segunda a sábado, das 8 às 9 horas da manhã. Aos sábados eram reprisadas as edições de sexta. Nesse período, o apresentador principal foi o bispo Júlio Freitas, que comanda também outros programas de rádio em Portugal e Espanha e é uma das lideranças da IURD na Europa. Em julho de 2012, havia um texto no site da IURD em Portugal em que o programa era comparado com uma corrida de automóveis:

\begin{abstract}
$06^{\circ}$ SENTIDO é o maior Pit Stop da corrida que é a vida. Assuntos práticos, de interesse pessoal, público, espiritual, familiar, físico, psicológico, económico, sentimental, empresarial, emocional... não há nenhum assunto, questão ou área da vida que fique por abordar no $6^{\circ}$ SENTID0, pois este é o programa mais abrangente que existe no cenário televisivo nacional (Freitas, 2012).
\end{abstract}

O texto apresenta a atração como um programa de variedades, no qual os mais diversos assuntos são abordados. A dimensão espiritual é apontada como apenas uma dentre outras e o programa não é descrito como "religioso" ou pertencente a uma denominação religiosa (leia-se IURD). No que se refere ao nome do programa, este remete ao fato de a IURD considerar que - além dos cinco sentidos naturais (audição, olfato, visão, tato e paladar) — há um "sexto sentido", que corresponde ao dom espiritual. Podemos perceber que, embora o programa seja descrito como uma atração que mostra um pouco de tudo, o elemento religioso permanece como fio condutor que passa por todas as outras dimensões.

Falaremos brevemente da estrutura do programa, dos quadros que o compõem nas diferentes transmissões. Para tanto, focaremos aqueles que foram transmitidos do dia 9 ao dia 13, visto que são os que contêm referências à sexta-feira 13.

3 Utilizamos como recorte os programas veiculados pela IURD em julho de 2012, especialmente as edições que antecederam o 13 de julho e que faziam menção direta à data (do dia 10 ao 13).

4 Encontramos dificuldades ao buscar informações sobre o "Sexto Sentido", já que o programa deixou de ser exibido em janeiro de 2013 e o novo portal da IURD em Portugal (http://centrodeajuda.pt/) não apresenta dados sobre ele. As informações de que dispomos originam-se de pesquisas que fizemos anteriormente e são aproximativas. Não temos como precisar, por exemplo, as datas exatas da primeira e da última edição do Sexto Sentido, mas o primeiro vídeo disponibilizado no antigo site datava de 24 de março de 2010, enquanto o último teria sido veiculado no dia 15 de janeiro de 2013. 
O programa começa com uma animação que mostra uma pequena planta verde de seis folhas em meio a um solo seco e repleto de rachaduras. Um feixe de luz sai do canto superior esquerdo e atinge a planta. Simultaneamente, gotas de água emergem da planta e sobem em velocidade e quantidade crescente para depois explodirem. Da explosão, resultam os caracteres em cor verde " 6 sentido", posicionados acima da planta, e uma fumaça que sobe em direção ao céu. A rápida abertura parece querer mostrar como o uso do dom espiritual (o sexto sentido) pode ser capaz de superar as condições mais adversas, de modo a fazer surgir a vida (a água) em um ambiente caracterizado pela ausência dela.

O programa é apresentado ao vivo e possui um formato fixo, com vários quadros. Há espaço para o público participar por meio de e-mails, que são lidos pelo apresentador e seu assistente. Nas mensagens, a pessoa pede um conselho ao bispo, este destaca em sua resposta a origem espiritual do problema e aconselha-a a ir a algum "Centro de Ajuda".

Apesar das vantagens do ao vivo, a exposição ao erro é maior, o que faz com que o cuidado com o roteiro seja tão rigoroso quanto nos programas gravados. No tocante ao " 6 o Sentido", identificamos uma estrutura que se repete na maioria dos programas. Por meio dela e da linguagem informal, procura-se mais do que despertar uma sensação de confiança, mas também de intimidade. Essa ambiência descontraída e dinâmica é marca da tevê, que passou de um primeiro momento marcado por uma distinção rígida entre informação e ficção (paleotevê) para uma tevê cuja característica definidora seria o entretenimento (neotevê):

Assim, substitui-se uma relação com base no contrato (cada programa apresenta um contrato comunicacional específico: informativo, ficcional etc.), por outra, marcada pela proximidade, pela convivialidade e pelo contato: 0 espaço televisual se confunde com o do cotidiano, através da relação afetiva e convivial do espectador. Assim, se num primeiro momento, a televisão se apresentava como hierárquica e contratual, cada vez mais se torna "um lugar de vida" para o espectador (Leal \& Valle, 2007, p. 2).

Após a abertura, o bispo Júlio Freitas dirige-se ao público utilizandose de frases de impacto que definem o tema do programa: 
Bispo Júlio Freitas (doravante BJF): muitos querem obedecer sem desafiar, mas isso não é possível, pois a condição para obedecer é a fé em prática, o desafio, pois sem fé em ação é impossível agradar ao criador que só pode entrar e fazer o sobrenatural acontecer, depois que você e eu entramos em ação por meio do nosso desafio, por meio do nosso sacrifício [...]. Bem, eu vou preparar o meu copo com água, espero que você já tenha o seu preparado (Sexto Sentido, 10/07/2012, 8h01).

Em seguida, o bispo cumprimenta Rodrigo, identificado na legenda na parte inferior da tela como "convidado". Rodrigo responde, saúda o público e lê mensagens enviadas por espectadores que narram problemas e pedem conselhos. Os dois respondem e nos conselhos enfatizam a importância de se ir ao Centro de Ajuda. Em seguida, mostra-se um testemunho de um fiel da igreja que enfrentou dificuldades, mas após conhecer a IURD teve sua vida transformada e, hoje, é feliz em todas as áreas da sua vida, mudança atribuída diretamente a sua adesão à igreja. No vídeo, a pessoa fala e suas ações são por vezes representadas por atores. Depois, volta-se para o estúdio e o bispo procura relacionar a história narrada com a vida do espectador e reitera o convite para ir ao templo.

Esse formato que agrega "narrativas de fracasso" (as mensagens lidas pelos apresentadores), "narrativas de sucesso" (os testemunhos), mediados e sucedidos por promessas de felicidade plena é recorrente nos programas da IURD. Essa "arquitetura narrativa" parece buscar promover uma "identificação-projeção” no público, a fim de fazer com que este vá a alguma das "reuniões" da igreja:

A identificação se daria pela narrativa de fracasso: ao refigurar tal narrativa em sua "experiência de leitura" o indivíduo aproxima os problemas narrados ("mundo do texto") dos seus ("mundo do leitor"), nesse processo ele é auxiliado pelos pastores, que por sua vez ampliam a abrangência dos depoimentos. A projeção ocorreria por meio das "narrativas de sucesso". A transição entre uma narrativa e outra é feita pela "promessa de solução" proposta pelo pastor ao espectador. Em seguida, o espectador toma contato com um testemunho que traz um problema semelhante ao exposto pela "narrativa de fracasso", mas agora com um desfecho distinto. Quando o personagem (que também é o narrador) chega ao ápice de seu sofrimento há o contato com a Universal. A partir daí sua vida se transforma e ele 
consegue solucionar o problema. A "narrativa de sucesso" funciona como prova de que a promessa do pastor é verdadeira. Ao refigurar a narrativa, 0 espectador que anteriormente se identificara com 0 problema narrado pode ser levado agora a acreditar que sua vida também pode ser modificada (Sousa, 2014, p. 124).

O formato é utilizado duas vezes a cada edição. Após a primeira "narrativa de sucesso", volta-se para o estúdio e o bispo Júlio Freitas surge com um copo de água nas mãos, faz uma oração, vale-se do exemplo do testemunho e menciona os espectadores na prece. Ele convida o público a beber da água e continua a oração, que dessa vez tem como foco os "patrocinadores mídia” do Centro de Ajuda, ou seja, aqueles que contribuem financeiramente para que a IURD sustente seus projetos nos meios de comunicação.

Após a oração, o bispo interage com Rodrigo e um deles retira um pequeno papel de uma caixinha que eles denominam "Caixa de Promessas”. Nele, há um trecho da Bíblia a partir do qual os apresentadores fazem uma reflexão em que costumam destacar que qualquer um pode alcançar o sucesso e a felicidade se fizer o "sacrifício" nos moldes que eles orientam. Como podemos perceber, tenta-se persuadir o espectador de que o que é dito é verdade por diferentes vias: seja pelas narrativas de fracasso e sucesso ou pela comprovação bíblica de que as "promessas" do bispo se cumprirão.

Na sequência, o Sexto Sentido traz conteúdos de caráter informativo. Exemplos:

1. Dias 09/07/2012, 10/07/2012 e 11/07/2012: sessão "Patrocinadores Mídia” do Centro de Ajuda. Um(a) fiel atribui a mudança em sua vida à IURD e afirma que o primeiro contato foi por algum programa de rádio ou tevê.

2. Dia 12/07/2012: vídeo sobre os 35 anos da IURD e a trajetória de Edir Macedo.

3. Dia 13/07/2012: Giro de notícias. A jornalista Sara Amante traz os destaques da Folha de Portugal (periódico da IURD que conta com conteúdo religioso e não religioso) e do jornal Eu Era Assim (exclusivamente religioso, apresenta testemunhos de fiéis da IURD). É 
exibido todos os dias e pode vir também em outros momentos do programa.

O programa continua com uma sequência parecida com a anterior: leitura de pedidos de ajuda (narrativa de fracasso); leitura de testemunhos (narrativas de sucesso) mediados por promessas de felicidade para quem frequentar as reuniões. Há também um momento de "estudo", como Rodrigo se refere no programa do dia 10/07/2012, quando lê um texto que versa sobre uma passagem bíblica. Em seguida, chama-se um vídeo em que outro testemunho dramatizado é apresentado. O programa volta para o estúdio e o bispo faz seu comentário sobre a narrativa apresentada e convida para as reuniões da igreja.

Em seguida, mais uma "narrativa de sucesso". Um pastor e uma fiel entram ao vivo em alguma cidade (Porto, Lisboa, Coimbra, Funchal etc.), normalmente próximos a algum templo da IURD. Na ocasião, o bispo e o pastor entrevistam um(a) fiel, que conta as dificuldades pelas quais passou até conhecer a IURD, bem como das mudanças positivas após realizar o sacrifício que lhe foi recomendado. Em algumas oportunidades, o pastor mostra as dependências do templo e destaca, assim, o conforto e o ambiente acolhedor.

O programa volta para o estúdio para comentários dos apresentadores sobre as reuniões. Rodrigo lê textos no blog que variam das reflexões do bispo Júlio Freitas a pedidos de ajuda e testemunhos. Em seguida, entram vídeos que podem variar de chamadas para reuniões (como as da sexta-feira 13; Fogueira Santa de Israel), chamadas dos jornais da IURD ou algum vídeo sobre as obras de caridade da igreja em Portugal.

Chama-nos a atenção os vídeos sobre os projetos sociais. Nossa hipótese é de que isso faz parte da estratégia iurdiana de mudar sua imagem na sociedade portuguesa. Além do nome "Centro de Ajuda", a ênfase nas obras sociais pode ter um efeito positivo para os propósitos da denominação em Portugal, principalmente se considerarmos a forte crise econômica pela qual o país passava em 2012, quando os programas foram veiculados. 


\section{$06^{\circ}$ Sentido e a sexta-feira 13}

Em 2012, a sexta-feira do dia 13 de julho foi a terceira do ano, o que, segundo os apresentadores, sugeriria que este era um ano "muito carregado". Os espíritos malignos estariam mais fortes, o que aumenta a importância de se ir à reunião de sexta-feira e fazer parte do "ritual sagrado" a fim de combatêlos. As referências à data começam no programa do dia 9 de julho (segunda) a partir de um convite feito pelo bispo. Reaparecem nos dias 10 e 11 e, com mais intensidade, no dia 12 . No dia 13 também encontramos menções, mas em menor quantidade. $\mathrm{O}$ quadro a seguir sistematiza tais referências.

\section{Quadro 1}

\section{Referências à sexta-feira 13 no Sexto Sentido}

\begin{tabular}{|c|c|}
\hline 09/7/2012 & $8 \mathrm{~h} 02$ - rápida fala do bispo no estúdio. \\
\hline $10 / 7 / 2012$ & $\begin{array}{l}\text { 8h50 - falas de Rodrigo e do bispo no estúdio. } \\
\text { 8h51 a } 8 \text { h55 - vídeo sobre a sexta-feira } 13 \text { (especialistas e pastor). }\end{array}$ \\
\hline $11 / 7 / 2012$ & $\begin{array}{l}\text { 8h26 a } 8 \text { h } 28 \text { - fala do bispo no estúdio. } \\
8 \mathrm{~h} 48 \text { - vídeo sobre a sexta-feira } 13 \text {. } \\
8 \mathrm{~h} 49 \text { a } 8 \mathrm{~h} 50 \text { - fala do bispo e de Rodrigo no estúdio. }\end{array}$ \\
\hline $12 / 7 / 2012$ & $\begin{array}{l}\text { 8h04 a 8h08 - fala do bispo no estúdio. } \\
\text { 8h08 a 8h10 - repetição do vídeo do dia } 11 . \\
\text { 8h10 a 8h12 - fala do bispo e de Rodrigo no estúdio. } \\
\text { 8h58 a 9h00 - vídeo com uma das especialistas do vídeo exibido no dia } 10 .\end{array}$ \\
\hline $13 / 7 / 2012$ & $\begin{array}{l}\text { 8h03 - vídeo - pastor com jovem possuído. } \\
\text { 8h55 a } 8 \text { h58 - continuação do vídeo anterior (pastor expulsa demônio de jovem possuído). } \\
8 \text { h58 - fala do bispo no estúdio. }\end{array}$ \\
\hline
\end{tabular}

Fonte: dados da pesquisa.

No dia 9 há apenas uma breve menção à sexta-feira 13; a partir do dia 10, passam a aparecer mais referências sobre a reunião de sexta.

BJF: sexta-feira 13 aqui em Portugal, em todo o mundo, as pessoas praticam o ocultismo, satanismo, a magia negra, a umbanda, a quimbanda, candomblé, a magia... a... que [...] destrói a vida de milhões de pessoas.

Rodrigo: [...] Raramente acontece de ter três sextas-feiras 13 no mesmo ano. Esse [sic] ano é assim, essa já é a terceira. Por isso que nós estamos falando pra você colocar um pacote de sal debaixo da sua cama e trazê-lo no Centro de Ajuda nessa sexta-feira 13. Nós vamos fazer aquele ritual sagrado com 0 altar, as sagradas escrituras e 0 sal que você vai trazer. Mas nessa sexta teremos um quarto ele- 
mento onde nós colocaremos sete pedras de sal... [...] consagrado

em Israel (Sexto Sentido, 10/07/2012, 8h50).

Nota-se uma aproximação dos significantes "ocultismo", "satanismo", "magia negra", "umbanda", "quimbanda" e "candomblé". Todos são atores que objetivam destruir as pessoas. Assim, o "mundo" construído narrativamente pela IURD apresenta-se como lugar em que forças antagônicas do Bem e do Mal duelam pela vida humana. Nesse "mundo" que o espectador apreende pela interpretação (mimese III), a magia e as religiões espiritualistas são apontadas como agentes malignos, enquanto a IURD se apresenta como aquela que faz o bem por meio do combate mágico/religioso (uso do "sal consagrado") a tais forças.

\section{Quadro 2 \\ Transcrição: Sexto Sentido (10/07/2012)}

\begin{tabular}{|c|c|c|}
\hline Hora & Imagens/ descrição & Áudio \\
\hline $8 \mathrm{~h} 51$ & $\begin{array}{l}\text { Música tensa, com crescentes e momentos de tensão na transição da fala de uma } \\
\text { pessoa para a outra. Ambiente escuro, em preto e branco e a arte em cor verde. } \\
1 \text { - Fundo cinza e texto com os dizeres: } 13 \text { Sexta-feira } \\
2 \text { - } \quad \text { Fundo cinza escuro: } 2 \text { mulheres de branco sentadas à frente e } 5 \text { pessoas } \\
\text { também de branco atrás delas de pé ( } 2 \text { homens e } 3 \text { mulheres). } \\
3 \text { - } \text { Homem negro que estava entre os } 7 \text { aparece sozinho e fala. Os participantes } \\
\text { falam olhando para o lado, como se conversassem com alguém. Ao final } \\
\text { olham para a câmera. [...] } \\
6 \text { - Uma das pessoas [Marcela Sousa] fala. } \\
7 \text { - Texto: inveja, maldições, pragas, bruxedos. [...] } \\
9 \text { - Uma das } 7 \text { pessoas (Cláudia) fala sozinha. [...] } \\
11 \text { - Uma das7 pessoas (Rosa) fala sozinha. } \\
12 \text { - Texto na tela: Estes conheceram os dois lados. [...] } \\
14 \text { - Uma das pessoas [Vera] fala sozinha. } \\
15 \text { - Texto: serviram por muitos anos forças ocultas. [...] } \\
17 \text { - Uma das pessoas [Luiza Oliveira] fala sozinha. } \\
18 \text { - Texto na tela: hoje estes sete servem à luz. } \\
19 \text { - Homem de paletó preto sentado no sofá olha diretamente para a câmera. } \\
\text { Depois, ele é mostrado neste sofá com seis das pessoas de branco atrás dele. } \\
20 \text { - Ele caminha e fala olhando para a câmera. Legenda: Fábio Shapowal: } \\
\text { especialista em casos sobrenaturais. } \\
21 \text { - Pastor com as pessoas de branco. Vários frames consecutivos, em cada um } \\
\text { deles ele está em um lugar diferente no meio das pessoas, como se alguma } \\
\text { força sobrenatural o teletransportasse. } \\
22 \text { - Texto: Traga um quilo de sal virgem/ Seja energizado com } 7 \text { grãos de sal/ } \\
\text { vindo de Jerusalém terra da luz. } \\
23 \text { - Pastor sentado no sofá olhando para a câmera com pessoas de branco } \\
\text { atrás dele em pé. } \\
24 \text { - Texto: } 13 \text { sexta-feira - entrada gratuita Centro de Ajuda Lisboa: Rua Dr. } \\
\text { José Espírito Santo, n. } 36, \text { Bairro das Amendoeiras. } \\
25 \text { - Imagens do pastor com as pessoas de branco. }\end{array}$ & $\begin{array}{l}{[. . .]} \\
6 \text { - Marcela Sousa: meu nome é Marcela Sousa. } \\
\text { Eu nasci e cresci em território macabro. Tive } \\
\text { sete tias que foram envolvidas com os encostos, } \\
\text { inclusive minha mãe e minha avó foram bruxas. } \\
9 \text { - Cláudia: meu nome é Cláudia e... eu conheci } \\
\text { o centro espírita com um ano e meio de idade. } \\
\text { Só saí com } 26 \text {. } \\
11 \text { - Rosa: me chamo Rosa e eu era tão carregada } \\
\text { que sete bruxos não resolveram meus problemas. } \\
14 \text { - Vera: eu chamo Vera. Fui serva de Iemanjá } \\
\text { à qual fiz muitos trabalhos. } \\
17 \text {-Luiza Oliveira: Eu me chamo Luiza Oliveira } \\
\text { e servi aos espíritos durante } 11 \text { anos e meio. } \\
20 \text { - Pr. Fabio Shapowal (PFS): Nós reunimos } \\
\text { essa equipe de especialistas no mundo } \\
\text { sobrenatural, pessoas que um dia serviram o } \\
\text { mal, mas hoje servem à luz para lhe [sic] ajudar } \\
\text { nessa sexta-feira desse [sic] ano tão carregado } \\
\text { que é o ano de } 2012 \text {. Aliás, essa é a terceira } \\
\text { sexta-feira } 13 \text { desse [sic] ano. Se você se sente } \\
\text { vítima de maldições, de inveja, forças do mal têm } \\
\text { atacado a sua vida. E você conclui isso porque } \\
\text { os problemas que você passa não são problemas } \\
\text { normais. Nessa sexta-feira } 13 \text { é a oportunidade } \\
\text { para você mudara situação da sua vida. Traga um } \\
\text { quilo de sal virgem. Nós iremos ensinar vocês } \\
\text { como vencer as forças do mal. } \\
23 \text { - PFS: Sexta-feira é a sua oportunidade } \\
\text { de vencer. }\end{array}$ \\
\hline
\end{tabular}

Fonte: dados da pesquisa. 
O vídeo se constitui a partir de micronarrativas que trazem personagens que falam de um passado negativo em que serviram às "forças das trevas”. A dinâmica narrativa se altera quando o pastor surge em meio às sombras e revela que eles são "especialistas no mundo sobrenatural" e que ajudariam a livrar as pessoas de todos os males.

Há novamente referências críticas às religiões mediúnicas. Fala-se em espíritos, Iemanjá, encostos e bruxaria. Todos são considerados forças malignas que visariam destruir a vida humana. A IURD parece entrar, tal como nos testemunhos exibidos, como aquela que redimiu a vida dessas pessoas e as levou para o caminho do bem. Isso fica sugerido tanto na fala do pastor quanto na de alguns personagens, que sempre demarcam narrativamente a partir de verbos no tempo passado para falar de sua relação com tais práticas. Rosa, por exemplo, diz que "era tão carregada que sete bruxos não resolveram” seus problemas e sugere que a IURD foi a responsável por essa mudança.

Os depoimentos acabam por funcionar como microtestemunhos que se assemelham às "narrativas de sucesso" (Sousa, 2014). No entanto, nesse caso específico, os personagens adquirem funcionalidade dupla. Não só atestam a existência das forças malignas das quais falam, mas também se tornam "especialistas" no assunto, e podem auxiliar a todos na batalha contra o "Mal". Ao reivindicar o termo "especialista" aproxima-se o discurso religioso do científico/médico, já que se valoriza a presença dessas pessoas pelo conhecimento que têm sobre as "forças do mal".

Além das menções negativas relacionadas às religiões espiritualistas e a aproximação com um discurso cientificista que ajudam a construir o "mundo" narrativo da IURD, notamos em uma das legendas (ver no quadro 2 o item 24) uma referência claramente ligada à dimensão comercial, quando se fala da "entrada gratuita". A menção à gratuidade pode ter a ver com uma tentativa da IURD de não se mostrar como igreja, mas como um órgão que, tal como empresas e ONGs, presta "serviços" à comunidade. Se considerarmos o contexto de inserção da legenda, pode-se cogitar, também, 
uma forma de se mostrar competitiva na disputa com as religiões mediúnicas e religiosidades que cobram pelos trabalhos realizados.

Por fim, cabe notar que a estética, o formato e a linguagem do vídeo assemelham-se à de trailers de filmes de suspense. A trilha sonora, com crescentes pontuais entre as falas dos participantes, somada aos efeitos visuais e às curtas falas, criam um clima de tensão e suscitam a curiosidade. O revezamento nos olhares, ora para o lado, ora diretamente para a câmera (e, por conseguinte, para o espectador), passa a sensação de que se conversa diretamente com o público, o que nessa situação parece significar que as forças malignas que povoam as narrativas iurdianas são parte não apenas daquele "mundo", mas penetra o mundo do espectador, tal como o olhar dos "especialistas". É um modo pelo qual a técnica televisiva articulada à construção narrativa do programa interpela o público a tomar aquelas narrativas como parte de sua vida. Após o vídeo, o bispo e seu assistente falam de pedidos de ajuda e convidam as pessoas a participarem da reunião de sexta.

No dia $11 / 07 / 2012$, a sexta-feira 13 foi abordada em três momentos. A primeira menção ocorre no momento em que o bispo e Rodrigo leem pedidos de ajuda no estúdio. Dessa vez fala-se em detalhes sobre o ritual que seria realizado na sexta-feira:

\begin{abstract}
BJF: A Isaura, de Porto Salvo, pede oração para a mãe que está com depressão. [...] Isaura, leva um quilo de sal nessa sexta-feira, mas antes coloca debaixo da cama da sua mãe. Ela não precisa saber. Coloca lá. E você recolhe esse um quilo de sal e leve no Centro de Ajuda e depois leve de volta, pra ela, depois de sexta-feira 13 porque vamos colocar sete grãos do sal de Israel consagrado em Terra Santa onde o senhor Jesus disse "bom é o sal" e vamos desfazer todo bruxedo, todo ritual, toda maldição, todo esse mal que tem feito a sua mãe estar nesse estado humilhante, caótico, depressivo, vergonhoso, isolada de tudo e de todos, superar tudo isso. E claro, depois você vai instruí-la a fazer uso desse sal. Você muda o sal que é na casa dela, lá na cozinha, pra que ela venha a fazer comida com esse sal, venha se alimentar desse sal. E ela se libertará (Sexto Sentido, 11/07/2012, 8h25).
\end{abstract}

Repete-se o que foi dito por Rodrigo no dia anterior, mas com duas diferenças. A primeira consiste no fato da menção à sexta-feira 13 vir asso- 
ciada a um pedido de ajuda, o que permite ao bispo relacionar as dificuldades à atuação das "forças do mal", o que torna o pedido, portanto, "prova" da existência delas. Já a segunda está relacionada às instruções dadas sobre os procedimentos a serem adotados com o sal: colocar debaixo da cama, levar ao templo e utilizá-lo em casa. O sal parece atuar absorvendo a energia negativa para, em seguida, ser purificado e tornado divino no ritual. Ao ser levado para casa e servir de alimento suas propriedades sagradas se transfeririam para aqueles que o consumissem, e resolveriam, assim, seus problemas e os "libertaria" das "forças malignas". No final do programa o assunto volta a ser abordado por meio de um rápido vídeo e nas falas dos apresentadores.

\section{Quadro 3 \\ Transcrição: Sexto Sentido (11/07/2012)}

\begin{tabular}{|c|c|c|}
\hline Hora & Imagens/ descrição & Áudio \\
\hline $8 \mathrm{~h} 47$ & $\begin{array}{l}\text { Música tensa ao fundo com crescentes. } \\
1 \text { - Imagens em preto e branco com tons verdes } \\
\text { em alguns momentos: gato preto, pessoa com } \\
\text { as mãos no rosto; espelho se quebrando, } \\
\text { número } 13 \text { com luz verde. } \\
2 \text { - Pessoas em situações de tensão surgem } \\
\text { a cada palavra citada: desmaios constantes, } \\
\text { vícios, depressão, doenças, medo, desejo } \\
\text { de suicídio, insônia, nervosismo, vultos ou } \\
\text { vozes. [...] } \\
6 \text { - BJF e Rodrigo (no estúdio). }\end{array}$ & $\begin{array}{l}1 \text { a } 5 \text { - Voz em off: maldição, azar, superstição. A sexta-feira } \\
13 \text { envolve todo um misticismo ligado ao infortúnio. Neste } \\
\text { [sic] dia acidentes, mortes, desastres acontecem em uma } \\
\text { escala avassaladora. Se a sua vida tem sido uma sequência de } \\
\text { problemas, de males constantes, depressão, vícios, doenças não } \\
\text { diagnosticadas pelos médicos, medo, desejo de suicídio, insônia, } \\
\text { nervosismo, visão de vultos ou audição de vozes, participe essa } \\
\text { sexta-feira dia } 13 \text { na reunião de Libertação [...]. } \\
6 \text { - BJF: [...] Porque isto [sic] é um sinal. Esse medo, essa } \\
\text { insegurança é um sinal da ausência do autor da vida na vida } \\
\text { pessoa. }\end{array}$ \\
\hline
\end{tabular}

Fonte: dados da pesquisa.

No vídeo listam-se os "sintomas que caracterizam a pessoa vítima da ação de um espírito”, como o bispo Júlio Freitas vai chamar no programa seguinte. Eles vão desde sinais que sugerem uma ligação direta com a dimensão religiosa (visão de vultos, audição de vozes) a problemas que podem ter origem psíquica (tentativas de suicídio, depressão) e a outros cuja abrangência pode levar qualquer espectador a se identificar (doenças não diagnosticadas pelos médicos, medo, insônia e nervosismo). Após o vídeo, o bispo ainda amplia a lista de sintomas ao incluir problemas de âmbito financeiro, familiar e de saúde. Assim, qualquer problema torna-se sinal da presença das forças malignas e da "ausência do autor da vida na vida da pessoa”, o que indica a necessidade de se participar da reunião de sexta. 
O dia 11 segue o padrão na construção narrativa de um mundo dividido pela guerra espiritual. A diferença fica por conta de especificar os efeitos das forças das trevas, os quais são de tal amplitude que qualquer um pode se identificar com algum deles ao refigurar tal narrativa (Ricoeur, 2010a). Ao dizer que combate tais problemas, resultando em uma vida de melhor qualidade para seu público, permanece a ideia da IURD como "prestadora de serviços" que atua em diversos seguimentos (espiritual, familiar, financeiro etc.).

A edição do dia 12/07/2012 é a que dedicou mais tempo à sextafeira 13. No início do programa o bispo lê três pedidos de ajuda e associaos à data. No primeiro um homem afirma ter problemas no casamento e o bispo o aconselha a colocar sal debaixo da cama com o seu nome, o da esposa e do filho e depois levar o pacote na sexta-feira ao Centro de Ajuda, de Vila Nova de Gaia. Ele repete a descrição do ritual, mas faz um adendo:

BJF: vamos fazer um trabalho com o altar, as escrituras sagradas e 0
sal que você vai levar Vítor. E vamos colocar sete grãos do sal consa-
grado em Israel, terra santa, onde o Senhor Jesus disse "que bom é o
sal". Na oportunidade, você vai receber a "pulseira da boa esperança"
[...]. E, claro, você vai receber o passe também da proteção nessa
sexta-feira (Sexto Sentido, 12/07/2012, 8h04-8h06).

É dito que o Vitor, o participante, irá receber a "pulseira da boa esperança”. Como se sabe, é comum tanto no catolicismo quanto em religiosidades místicas os crentes usarem pulseiras e colares porque acreditam ter algum poder espiritual que oferece proteção contra "espíritos malignos”. As referências a outras religiões - e incorporação de aspectos destas que Oro (2007) define como uma característica "religiofágica” da IURD — também reaparece no momento em que se fala de um "passe da proteção", já que a palavra "passe" está incorporada ao Kardecismo. Da mesma maneira que aborda a sexta-feira 13, a Universal assume esses elementos para si e os investe de um novo significado. $\mathrm{O}$ que em outro plano é negativo e ligado ao Mal, na Universal ganha contornos sagrados.

Em seguida, outro caso é abordado. Nele, uma mulher deseja melhorar a relação com o marido e o bispo a convida a ir ao templo. Ele fala dos 
rituais malignos feitos nesse dia e cita outra pessoa que pediu ajuda por telefone e disse ter sido amaldiçoada por alguém que "chegou ao extremo de pagar a um bruxo para que lhe fizesse um ritual, um bruxedo. Foi despachado, foi entregue, foi oferecido esse bruxedo e desde então tudo passou a dar errado" (Sexto Sentido, 12/07/2012, 8h07-8h08). Novamente, atestam-se a existência e a força dos espíritos malignos, bem como a necessidade de se ir à reunião da IURD.

Subsequente ao comentário, o vídeo exibido no dia anterior é reprisado. O programa volta ao estúdio com Rodrigo e o bispo que tecem comentários sobre a sexta-feira a partir de pedidos de ajuda. A última referência à data nessa edição se dá ao fim do programa, quando uma das especialistas do vídeo do dia 10/07/2012 fala sobre os espíritos malignos.

\section{Quadro 4 \\ Transcrição: Sexto Sentido (12/07/2012)}

\begin{tabular}{|c|c|c|}
\hline Hora & Imagens/ descrição & Áudio \\
\hline $8 \mathrm{~h} 58$ & $\begin{array}{l}\text { Música tensa ao fundo. } \\
1 \text { - Imagens em preto e branco com tons verdes. } \\
\text { Número } 13 \text { surge com as luzes verdes na parte } \\
\text { inferior. } \\
2 \text { - Luísa Oliveira, uma das especialistas, fala sobre } \\
\text { os rituais. Atrás dela, uma folhagem verde vibra. } \\
\text { Imagens em tom próximo ao preto e branco, de } \\
\text { modo que o rosto dela parece pálido. Legenda: } \\
\text { Luísa Oliveira } 11 \text { anos Mãe de Santo. [...] } \\
4 \text { - Luísa Oliveira fala no mesmo local. }\end{array}$ & $\begin{array}{l}2 \text { - Luísa Oliveira: [...] são trabalhos de muita força, } \\
\text { são trabalhos em que os grupos de espíritos se reúnem } \\
\text { precisamente para fazer esses trabalhos mais fortes. } \\
4 \text { - Luísa Oliveira: [...] nessa sexta-feira } 13 \text { [os trabalhos] } \\
\text { são feitos, digamos, que pelos cabeças, pelos chefes dessas } \\
\text { falanges, pelos chefes desses grupos de entidades... [...] } \\
\text { dão efeito muito mais forte, dão efeito muito mais rápido } \\
\text { porque não é feito só pelos pequenos, é feito pelos grandes, } \\
\text { é feito pelos hierárquicos dentro da... do espiritismo, de } \\
\text { outro... da bruxaria, não é? Dentro da feitiçaria... }\end{array}$ \\
\hline
\end{tabular}

Fonte: dados da pesquisa.

No vídeo traz-se novamente outra peculiaridade da sexta-feira 13, dia em que os trabalhos são feitos, não pelos espíritos pequenos, mas pelos "cabeças". Esse vídeo complementa o dos "especialistas". Luísa Oliveira, que na ocasião anterior é apresentada como especialista, agora atua como tal, falando sobre a sexta-feira e reafirmando a existência e força dos espíritos malignos. Tal como nas falas do bispo, o espiritismo se torna sinônimo de bruxaria e feitiçaria que estão ligadas às forças do mal. 


\section{A edição do dia 13 foi dedicada à reunião da Fogueira Santa de Israel}

(a mais importante da IURD) que seria realizada no domingo daquela semana. Provavelmente devido a esse fato falou-se menos da sexta-feira 13 do que esperávamos. No entanto, as referências à data são significativas e fazem com que esse programa destoe dos demais. No início, o bispo e Rodrigo referem-se à sexta-feira 13 e exibem parte de um vídeo em que um ritual de exorcismo é realizado e é retomado ao final do programa.

\section{Quadro 5 \\ Transcrição: Sexto Sentido (13/07/2012)}

\begin{tabular}{|c|c|c|}
\hline Hora & Imagens/ descrição & Áudio \\
\hline $8 \mathrm{~h} 58$ & $\begin{array}{l}1 \text { - Apresentadores no } \\
\text { estúdio. Legendas: Hoje, } \\
13 \text { de julho, especialmente } \\
\text { às } 20 \mathrm{~h} \text {, mas também } 10 \text {, } \\
12 \text { e } 15 \text { h. } \\
2 \text { - Entrevista com pessoa } \\
\text { possuída no templo. O } \\
\text { pastor Fabio Shapowal, } \\
\text { que é aquele que aparece } \\
\text { junto aos especialistas } \\
\text { em outro vídeo, conversa } \\
\text { com pessoa possuída e } \\
\text { a liberta do espírito que } \\
\text { a possui. Ele traja roupa } \\
\text { branca, enquanto seu } \\
\text { interlocutor tem sobre os } \\
\text { ombros um pó branco que } \\
\text { provavelmente é o sal. } \\
3 \text { - BJF no estúdio com } \\
\text { Rodrigo. }\end{array}$ & $\begin{array}{l}1 \text { - BJF: e quem criticar esse trabalho (o ritual da sexta-feira } 13 \text { ) é porque é } \\
\text { perturbado. Ah, mas é o padre, ah, mas é o meu vizinho, mas é o meu filho, ah, mas } \\
\text { é o guru. Ele também é um perturbado, endemoniado [...]. Vamos então concluir } \\
\text { as imagens que a gente exibiu logo no início do nosso programa. [...] } \\
2 \text { - Pastor Fabio Shapowal (doravante PFS): abriu no corpo dele. (Homem: grrr) } \\
\text { Você é o chefe? } \\
\text { Homem (voz rouca e raivosa): eu sou! [...] } \\
\text { PFS: quais pensamentos você coloca? } \\
\text { Homem: negativo. } \\
\text { PFS: como qual? } \\
\text { Homem: desistir, não vai dar certo. Não vai dar certo [...] } \\
\text { PFS: você é o espírito que estava no pai dele? } \\
\text { Homem: é... [...] } \\
\text { PFS: acabou, é agora. Olha pra mim, meus olhos, olha pra mim, vira pra cá. [...] } \\
\text { Homem: vou levar igual eu levei o pai dele. } \\
\text { PFS: vai levar nada! Porque a partir do momento que ele entrou naquela porta a } \\
\text { luta dele passou a ser minha. } \\
\text { Homem: é grande, viu? [risada] } \\
\text { PFS: é grande? Então agora! Vamos ver quem é o mais forte. Aqui tem o espírito } \\
\text { cabeça. Você é o espírito cabeça no terreiro. E em mim há um espírito também. } \\
\text { Quem é mais forte? Nos meus olhos, olho pra olho. De alma pra alma. A alma dele } \\
\text { pelos olhos o espírito alcança. Você pode alcan... pode enxergar, olhar pra minha } \\
\text { alma pelos olhos dele. Só pode ficar um de pé. } \\
\text { Homem: [Grita forte enquanto se abaixa até ficar ajoelhado. O pastor olha fixamente } \\
\text { para os olhos dele]. } \\
3 \text { - BJF [fala enquanto o homem grita]: Esse trabalho de libertação realizado pelo } \\
\text { Centro de Ajuda tem permitido pessoas em todos os continentes de se libertarem } \\
\text { de espíritos hereditários, praga, bruxedo, maldições. [...] }\end{array}$ \\
\hline
\end{tabular}

Fonte: dados da pesquisa.

O trecho acima difere da forma como o programa vinha sendo conduzido. A primeira diferença diz respeito a uma referência negativa a membros da Igreja Católica que criticam os rituais da Universal. Esta foi a única menção de caráter crítico em relação ao catolicismo nos programas analisados. 
A outra consiste no uso das famigeradas "entrevistas com o demônio". Nelas, faz-se uma série de perguntas relacionadas à origem do espírito maligno, suas intenções e força, o que constrói uma breve narrativa sobre ele. O suposto demônio responde com uma voz rouca e raivosa, entrecortada por risos debochados e gritos. Em seguida, o pastor o ameaça e o desafia a demonstrar. Após uma "batalha espiritual”, o pastor vence e o espírito abandona a pessoa, que volta a falar com voz natural.

Do conteúdo apresentado sobre a sexta-feira 13 este é o que talvez possa mais impressionar o público. Enquanto os demais vídeos apresentavam o pastor e os especialistas como autoridades e faziam uso de efeitos visuais que assemelhavam tais narrativas a filmes de suspense, a entrevista com o diabo se dá com uma pessoa real em um num ambiente físico ao qual o público pode ter acesso com facilidade (templo da IURD). Assim, se antes o mal era apresentado por meio de uma estética que dizia respeito à ficção ou era simplesmente mencionado na fala dos apresentadores, na entrevista com o demônio ele se materializa em uma pessoa, o que pode contribuir para afastar as dúvidas de um público mais cético.

\section{Considerações finais}

O Sexto Sentido se apresenta como um programa leve e descontraído. Além disso, há um destaque para as ações sociais desenvolvidas e pedidos de contribuição para sustentar os seus programas. Esses dois fatores contribuem para sustentar uma imagem positiva da IURD em Portugal, como uma ONG, um "Centro de Ajuda”, o que acaba por distanciá-la do significante "igreja”, que, aliás, não é utilizado para se referir à IURD.

Ao tomar a abordagem ricoeuriana por base para nossa análise, atentamos para o modo como a IURD se relaciona com os demais setores da sociedade portuguesa e com a sua própria história (mimese I) e, ao fazê-lo, investe de sentido referências que pertencem a um universo não necessariamente cristão (as religiões mediúnicas, a magia e a bruxaria) e nem religioso (a ciência, o estado, o financeiro), o que marca permanências e desvios nesse processo (mimese II).É por meio de uma leitura analítico-interpretativa que ao refigurarmos (mimese III) tais narrativas conseguimos identificar 
a proposição de um "mundo textual” em que forças espirituais antagônicas duelam pelas almas humanas, "mundo" que as narrativas procuram demonstrar que é o mesmo habitado pelo espectador.

O tom ameno do programa modifica-se nas menções à sexta-feira 13, que trazem à tona um mundo sombrio habitado por forças malignas que visam destruir os seres humanos. Propõem-se uma equivalência no plano espiritual entre Umbanda, Kardecismo, Candomblé e bruxaria, como sinônimos de agentes das trevas. Na sexta-feira 13, o dano na vida das pessoas seria maior porque os "trabalhos" seriam realizados pelos espíritos malignos que ocupam um lugar superior na hierarquia. Para saber se realmente se é vítima de tais "forças", o programa apresenta uma série de sintomas que possuem grande generalidade e abrangência, que vai dos problemas financeiros a psicológicos, de modo a fazer com que qualquer um possa identificar alguma ação dos espíritos malignos na sua vida.

Absorvendo o discurso científico, a IURD traz "especialistas do mundo espiritual" que conhecem tais forças e chamam a atenção para seus poderes, dado que também já atuaram como seus servos. Indicando sintomas e apoiando-se nos especialistas, prescreve-se o tratamento adequado, qual seja: ir à reunião de sexta, na qual um ritual diferenciado, ou seja, adequado para aquela ocasião, seria realizado como resposta aos trabalhos e com o objetivo de se fornecer proteção e combater os agentes do Mal.

No tocante à forma como os conteúdos são apresentados, verificamos que há uma crescente. A cada dia novos elementos verbo-visuais são inseridos de modo a procurar convencer gradativamente o público que os espíritos do Mal personalizados nas outras religiões e religiosidades existem e afetam as vidas das pessoas, indicando, logo, a urgência em ir a algum templo da igreja. Se o primeiro vídeo possui o formato de um de trailer de filme de suspense e, portanto, suscita a curiosidade do público, os demais revelam pouco a pouco outros elementos referentes ao ritual e à sexta-feira 13 (sintomas, o porquê de os espíritos estarem mais fortes nessa data) até que o Bem e o Mal se confrontam no exorcismo. 
Percebemos que a sexta-feira 13 consiste em mais um elemento que a IURD traz para sua cosmologia religiosa, segundo a qual os seres humanos se dividem entre os que fizeram o "pacto" com o Criador e os que estão à mercê das forças das trevas por não o terem feito e aqueles que servem diretamente ao Mal. Essa característica "religiofágica” (Oro, 2007) aponta para a grande capacidade adaptativa da igreja em um contexto diferente do de sua origem (o brasileiro). Assim, ao comparar os dois cenários (brasileiro e português), verifica-se que o Sexto Sentido, além de ser mais suave e descontraído que os programas da IURD no Brasil, também dá destaque às ações sociais, faz poucas referências negativas ao catolicismo e inclui a bruxaria e seus bruxedos no hall das forças malignas que visam destruir vidas (a Umbanda, o Candomblé, o Kardecismo). Do mesmo modo, ao se aproximarem datas importantes para a cosmologia iurdiana, o programa pode se modificar e seu caráter descontraído dá lugar a momentos de tensão, tal como ocorre nas edições que fazem referência à sexta-feira 13 .

A IURD, ou o Centro de Ajuda, adapta-se e transforma-se conforme a demanda; mostra aspectos em Portugal que não são valorizados no Brasil. A IURD enfatiza a existência de forças malignas específicas em cada contexto social e religioso, mas permanece se reafirmando como a única capaz de confrontá-las e proporcionar uma vida próspera e feliz aos seus fiéis.

\section{Referências}

Leal, B. S. e Valle, F. (2007). O telejornalismo entre a paleo e a neotovê. Contemporânea - Revista de Comunicação e Cultura, 5(1), 1-14. Disponível em http://www.portalseer.ufba.br/index.php/contemporaneaposcom/article/view/3513/2567. Acesso em 3 out. 2013.

Mafra, C. (2001). Os evangélicos. Rio de Janeiro: Jorge Zahar Ed.

Modesto, C. F. (2012). 34 anos de evangelismo eletrônico. Observatório da Imprensa. Disponível em: http://www.observatoriodaimprensa. 
com.br/news/view/_ed694_34_anos_de_evangelismo_eletronico. Acesso: 12 ago. 2013.

Oro, A. P. (2007). Intolerância Religiosa e Reações Afro no Rio Grande do Sul. Em Silva, V. G. (Ed.), Intolerância Religiosa: impactos do neopentecostalismo no campo religioso afro-brasileiro (pp. 29-69). São Paulo: Editora da Universidade de São Paulo.

Ricoeur, P. (2010a). Tempo e Narrativa: a intriga e a narrativa histórica Tomo I. São Paulo: Martins Fontes.

Ricoeur, P. (2010b). Tempo e Narrativa: o tempo narrado - Tomo III. São Paulo: Martins Fontes.

Ruuth, A., Rodrigues, D. (1999). Deus, o Demónio e o Homem: a Igreja Universal do Reino de Deus. Lisboa: Colibri.

Sousa, M. T. (2014) As narrativas do Reino: Análise narrativa de programas televisivos da Igreja Universal nas madrugadas mineiras. (Dissertação de Mestrado em Comunicação Social). Programa de Pósgraduação em Comunicação Social da Universidade Federal de Minas Gerais (UFMG), Belo Horizonte, Brasil.

Swatowiski, C. (2010). Igreja Universal em Portugal: tentativas de superação de um estigma. Intratexto, no especial 1. Disponível em: http://www.epublicacoes.uerj.br/index.php/intratextos/article/view/416a Acesso: 5 nov. 2012. 